\title{
UTILIZATION OF NEGLECTED MONUMENT BUILDINGS
}

\author{
Adrienn MISLYENÁC \\ University of Pécs, Faculty of Engineering and Information Technology, Department of Visual Sciences. Pécs, \\ Hungary, aadikaa96@gmail.com
}

\begin{abstract}
The larger part of Pécs's downtown area - an area that still preserves the structure of the medieval city - is protected either by local or national regulations. Although the street structure within the limits of the city wall have not changed, the cityscape has undergone more transformations, since every architectural era has left its dominant mark in the buildings. In this study I will analyse one of the most important East-West axes of the downtown, and in more specific detail the Király Street with its historically important buildings. I will describe the history of its development, its past and present function, and the changes that this area has undergone up to the present day. In addition to the architectural aspects of these changes, transport, trade, and tourism also play an important role. In this study, I would like to draw attention to the currently vacant, incorrectly used properties and opportunities for their use in the future.
\end{abstract}

Keywords: monument buildings, downtown, Király Street, public spaces, Pécs.

\section{Introduction, objectives}

Pécs seemed to be the best choice as a subject for our studies and research of the protection of historic buildings: The city's downtown area has a significant historical background, and there is a large number of old monument buildings hidden in the city centre's medieval street system. Some of these buildings were built in the XV. Century, which in itself is sufficient motivation for such research. As we delved deeper and deeper into our survey of the city's history the aims of this research became clearer. The large number of unoccupied, unused buildings in the downtown area came to the forefront of our attention. It was sad to see that these historically important buildings have become nothing more than mere parts of the scenery, useless decorative elements of the streets. As we were walking in the city we noticed Király Street in the downtown area. We had (and still have) knowledge of its history, its development, so we were aware of the kind of history that this area has.

We were saddened by the sight of the long rows of lifeless, unused buildings, in a state totally unfitting of old monuments. Király Street used to be one of the most significant trade routes during the Middle Ages, it functioned as the main street of the historical downtown area.

We began to think of the possible factors (conscious or not) that can determine the emptying of a building, we decided that as long as these were not clear to us it would be futile to even begin finding a solution. Besides the infrastructural point of view we considered the presently existing functions as another important aspect to be analyzed. Even in the last few years there have been major changes, shops and businesses frequently open, close down or change.

\section{Historical review}

\subsection{Historical review of the downtown of Pécs}

The biggest part of the downtown area is protected by either local or national regulations, therefore its shape still preserves the structure of the medieval city. This means that this structure was largely complete even before the Turkish occupation, the Turks made only minor changes, raising very few buildings. The biggest modifications were made during the liberation wars, when entire streets with all their buildings were completely destroyed. The city centre was rebuilt 
following the old street structure, new buildings were raised in place of the old ones, and in fact many new houses were built upon the surviving foundations of the demolished ones.

Although the street grid of the walled downtown area has suffered little change, the cityscape itself has gone through major transformations over the centuries, the dominant elements of each architectural style and age left its mark on the buildings, sometimes by removing elements of older styles. At around the end of the 18th century the old city walls began to disappear as they no longer had any significant role in the city's military defence system, nor were they useful in any other way, on the contrary: the structure rather impeded the further development of the city. The gates that used to serve as entry and exit points were not spared either; the walls were broken through in many places, in fact we can observe this historical process even today at the Barbakán near the old Western gate. Fortunately the historically valuable city hall is still mostly preserved along with the towers, mostly on the Northern side where longer, contiguous portions still exist. [1]

\subsection{Király Street's historical review}

Király Street was for many centuries the main street of Pécs's downtown area, for which there is ample written evidence both in documents and old street names. Together with Ferencesek Street it forms the main East-West axis of the city center. It led towards the old Budai gate, the likely place of which we only know because of one inscription that can be found in the place where the gate itself once probably stood.

In 1554 the street's name was Nagy uca mahlle, we know this from old Turkish taxation documents that constitute one of our most important written sources of language from that age. Mahallé means tax district, which the Turkish Inland Revenue office supplied with a Hungarian street name in order to locate taxpayers more efficiently.

Between 1695-1891, after the Turkish occupation, this street became the home of many small businesses and shops that provided the large majority of services. The name Stern also indicates that this street was once a star of the city. Later it became Hauptgasse in 1804, and Főutza in 1856. These names indicate the street's crucial role in the historical downtown area. During those times, Pécs became the home of many different ethnic groups, the largest of which was the Germans, which is why the language of the cadastre became German and many German street names became common.

Between 1877 and 1890, many manufactures operated in the downtown area and also in Király Street. In this period, more precisely in 1864, the pedestrian street acquired its present name, after József Király, who was a bishop of Pécs.

Beginning with the XX. Century, and especially in the century's second half, this street became the downtown area's trade district. In this time the street was named after Kossuth Lajos but it got back its old name in 1991. [3]

\section{Conclusions}

During our investigation, the function and placement of the different squares became clear. (These squares function as centres of gravity in the street, the eastern centre of gravity is at Búza Square, which is the end point of Király Street; the western point is the city centre, where we can find Széchenyi Square. Along the street we can find pretty much every kind of important function from commerce to hospitality businesses.

We noticed that the different commercial functions are scattered along the entire length of the street. There are smaller convenience stores, different shops, all sorts of merchandise is being sold here unsurprisingly, since this street has been a home for merchants even from the Middle Ages. Some businesses are convenience stores selling mainly food products, others provide services such as hairdressers. In the future it would be beneficial if, through mutual support, they could form some sort of healthy competition offering similar, yet different products and services. From the point of view of the deserted buildings it would be optimal if these would be occupied by small businesses, possibly open space shops that could make use of the internal spaces, e.g. the courtyards of these buildings. Thus we could build upon the history of the place yet these businesses would also integrate into a coherent environment. This would bring the street back to life, also would be an attraction point for tourists.

There is a large number of restaurants, bars and similar businesses in the street, noticeably more towards its Western part, around the Széchényi Square, As an area for tourism the two endpoints of the street: Széchenyi square and Búza square, are more significant because these spots have a more central place in the city's life, their historical value is also greater. The eastern part of the street has hardly any such function. Búza square 


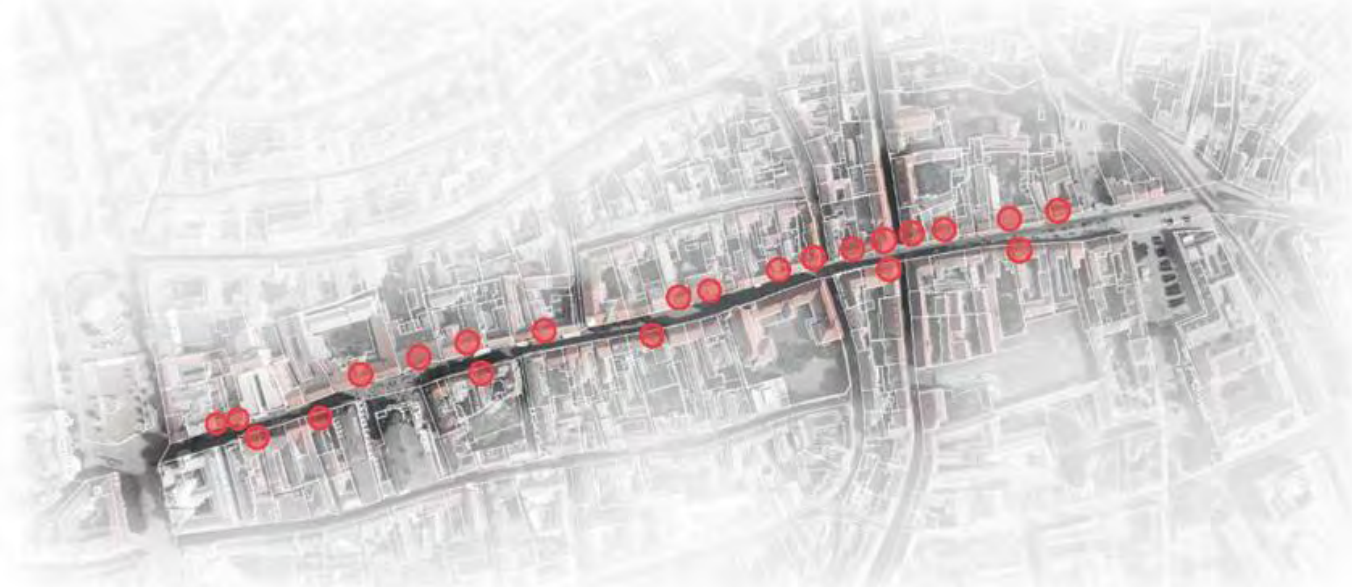

Figure 1. Empty real estate on Király Street

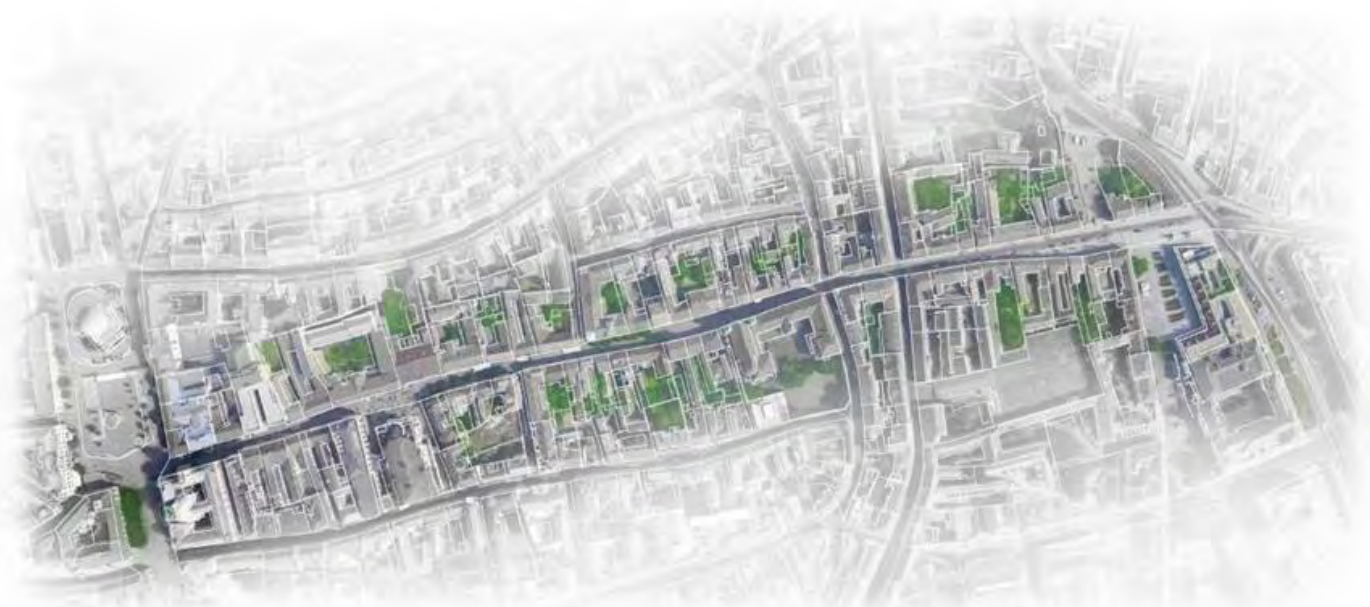

Figure 2. Green surfaces on Király Street

is used less than it could be, events should be organized there to make it function as a bridge towards the Eastern part of the city and the culturally more active neighbourhood.

Several educational institutions are located in the downtown area, the students of which could participate in different afternoon programs in order to gain insight into the manufacturing and production processes of the unique products that are made here.
On the street the different functions are constantly changing, many businesses moved into larger malls, leaving their former premises empty, but we also see bigger monumental buildings with their entire ground floor or sometimes the whole building completely vacated as is the case of the former downtown restaurant.

Following the first steps of our research, we have come to the conclusion that it is worthy and necessary to maintain this most significant pedes- 
trian street in Pécs. We must bring the deserted monuments back to life, we cannot surrender them to oblivion, because our past is not something insignificant that we should just ignore and forget!

These ancient monuments are able to satisfy the needs of the present age, while also preserving their historical significance.

They could provide adequate space for those functions that contribute positively to the life of the street.

\section{References}

[1] Bezerédy Gy., Madas J.: Pécs belváros telkei és házai - Adatgyüjtemény. Pécs, 1978, source available: Pécs, Tudásközpont, local history section

[2] Fedeles T.: Utcák, terek, épületek Pécsett - Baranya historical announcements, Pécs, Yearbook of Baranya County Archives, 2010

[3] Pesti J.: Pécs utcanevei 1554-2004. Pécs, source available: Pécs, Tudásközpont, local history section. 